\title{
Serum Chemistry Measurement
}

National Cancer Institute

\section{Source}

National Cancer Institute. Serum Chemistry Measurement. NCI Thesaurus. Code C61014.

A quantitative measurement of a particular substance present in a sample of serum. 